\title{
Między dźwiękiem a obrazem w języku chińskim
}

\author{
Between sound and image in Chinise
}

\section{Ewa ZAJDLER}

Uniwersytet Jagielloński/ Jagiellonian University in Kraków

E-mail: e.zajdler@pro.onet.pl

\begin{abstract}
Chinese is a tonal language, thus the difference in the tone is directly linked to the word meaning. There are four tones in Mandarin Chinese. The sound pitch is as distinctive as the components of segmental phonemes of the syllabic structure. Different morphemes/words in the Chinese language can sound alike or the same. It is the combination of the components in the Chinese character which can indicate the meaning as well as partially or wholly the pronunciation. In the paper we discuss some radicals of the traditional writing system in the relation to the phonetic components (phonetic indicators) in the picto-phonetic characters (known also as phono-semantic characters). Whoever tries to learn the Chinese language as L2 has to approach the writing system in order to develop the vocabulary and the spoken Chinese language competence.
\end{abstract}

Keywords: chinese language, tones, tonal language, chinese characters, radicals

\section{Wstęp}

Przyjmując perspektywę komunikacji językowej, definiujemy język jako „[s]ystem znaków (prymarnie dźwiękowych, wtórnie pisanych i in.) służących do porozumiewania się w obrębie danej społeczności” (K. Polański 2003: 269). W języku chińskim relacja między systemem dźwięków i systemem zapisu treści wykazuje pewne zależności w znakach piktograficzno-fonetycznych tj. takich, „w których jeden element [graficzny] wskazuje na zakres semantyczny znaku, a drugi na jego przybliżoną wymowę" (M.J. Künstler 2000: 48). Zależności te istnieją pomiędzy strukturą sylabiczną i strukturą zapisu znakiem pisma chińskiego. Pamiętać należy, że język chiński nigdy nie przekroczył progu zapisu fonetycznego, choć znaki, w których komponent fonetyczny wskazuje w większym lub mniejszym stopniu na wymowę sylaby, stanowią we współczesnym języku ponad 75\% wszystkich znaków (M.J. Künstler 2000: 48).

\section{Sylaba vs. znak chiński}

Tradycja chińska opisuje monosylabiczny wyraz jako ciąg dźwięków nagłosu i rymu, w skład którego wchodzi fonem tonalny. Odwołuje się przy tym do dwóch znaków chińskich zapisujących monosylabiczne wyrazy, w których odpowiednio wskazany jest: w pierwszym - nagłos, a w drugim - wymowa wygłosu. Metoda ta znana jako 
反切 fănqiè od III wieku n.e., przetrwała do XX wieku ${ }^{1}$. Najstarszy zachowany słownik rymów 《切韻》Qieyun z przełomu VI i VII wieku n.e. korzysta z tej metody; podaje w tabelach znaki chińskie uporządkowane według ówczesnej wymowy (M.J. Künstler 2000: 27-28). Miał on stanowić swojego rodzaju przewodnik po wymowie wyrazów w poezji (gdzie rym grał rolę), a szerzej, w tekstach klasycznych. Postrzeganie wymowy monosylabicznego wyrazu w kategoriach nagłosu i wygłosu zachowało się także w używanej do dziś na Tajwanie transkrypcji fonetycznej zhùyin fúhào 注音符號.

\section{INITIALS}

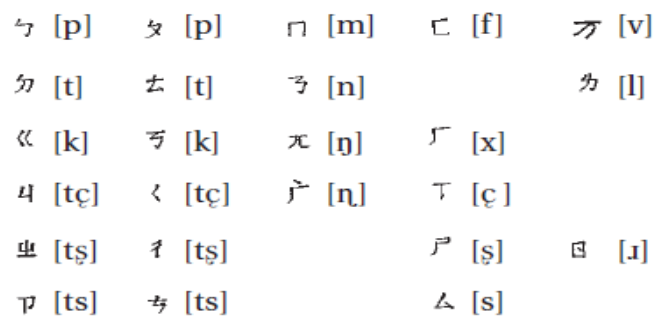

\section{MEDIALS}

I $\quad[\mathrm{i}] \quad \times[\mathrm{u}] \quad \sqcup[\mathrm{y}]$

\begin{tabular}{|c|c|c|c|c|c|c|}
\hline & & & FINALS & & & \\
\hline$Y \quad$ [a] & ट [o] & ट [y] & 甘 $[\varepsilon]$ & 5 [ai] & ح [ei] & 幺 [ao] \\
\hline 邓 $[\mathrm{ou}]$ & 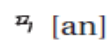 & ム [ən] & え $[\mathrm{an}]$ & $\angle$ [əп] & 儿 $\left[\partial^{2}\right]$ & \\
\hline
\end{tabular}

Tabela 1. Zapis transkrypcji fonetycznej zhùyin fühào 注音符號 (P. Chen 1999: 181).

We współczesnym języku chińskim nieobligatoryjna spółgłoska stanowi nagłos sylaby. Samogłoska prosta, dyftong lub tryftong wraz opcjonalną spółgłoską wygłosową $-n$ lub $-\mathrm{y}$ stanowi jej wygłos.

$$
\begin{aligned}
& \text { samogłoska } \\
& \text { spółgłoska }+ \text { samogłoska } \\
& \text { samogłoska + spółgłoska } \\
& \text { spółgłoska }+ \text { samogłoska }+ \text { spółgłoska }
\end{aligned}
$$

Podział na nagłos i wygłos jest wyraźny w fonetycznym zapisie zhùyin fúhào 注 音符號, ale już nie w obecnie ogólnie przyjętej w publikacjach i w dydaktyce transkrypcji alfabetem łacińskim 漢語拼音 hànyǔ pinnyīn (pinyin).

Dźwiękowa realizacja języka chińskiego doskonale wpisuje się w założenia fonologii segmentalnej. Mocno ograniczona łączliwość nagłosów i wygłosów daje zamknięty zbiór sylabemów. Ciąg głosek z sylabotwórczą samogłoską jest morfemem

\footnotetext{
${ }^{1}$ Przykładem może być encyklopedia 《辞海》z 1936 roku, z której przedruk w zakresie pojedynczych znaków znajdujemy w słowniku znaków języka klasycznego 《中華小字典》z 1985 roku.
} 
leksykalnym i/ lub gramatycznym, często swobodnym, zważywszy na monosylabiczność jako cechę typologiczną języka chińskiego ${ }^{2}$. Ton (a precyzyjniej: fonem tonalny) jest atrybutem fonologicznym każdej pojedynczej sylaby, zwanej sylabemem na poziomie sekwencji dźwięków (segmentu mowy) w odróżnieniu od sylaby chińskiej, spełniającej kryteria cech dystynktywnych tonalności. To zespół cech dodanych do samogłoski, która łączy w sobie cechy segmentalne samogłoski sylabotwórczej i suprasegmentalne - zmienną częstotliwość dźwięku w czasie w skontrastowanej pięciostopniowej skali infleksji i diapazonie danego tonu (E. Zajdler 2010: 275). Zarówno na poziomie sylabemu, jak i sylaby język chiński wykazuje wysoki stopień homofoniczności. Nie jest to oczywiście przeszkodą w komunikacji dla użytkowników języka chińskiego jako L1, a przyjmując komunikatywny poziom kompetencji chińskiego jako obcego i strategię radzenia sobie z kontekstem gramatycznym, także dla obcokrajowców. Jest to jednak cecha języka utrudniająca naukę chińskiego dorosłym na wszystkich etapach, ale szczególnie na etapie początkowym. Skonfrontowanie znaczenia nie tylko z dźwiękiem, lecz także z zapisem pozwala odróżnić tak samo brzmiące wyrazy. I tu jest miejsce na refleksję nad wtórnym wobec mowy zapisem języka.

Komponenty danego znaku, niezależnie od tego, ile ich jest, zajmują przeznaczoną dla znaku określoną przestrzeń zbliżoną do kwadratu. Można wyłonić struktury kompozycji znaków. N. Kordek (2013), odwołując się do standardu Unicode, proponuje 12 struktur kompozycyjnych (nie wliczając znaku niepodzielnego na mniejsze elementy kompozycyjne); inni autorzy wyłaniają ich więcej dla celów dydaktycznych:

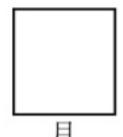

月
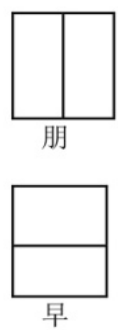
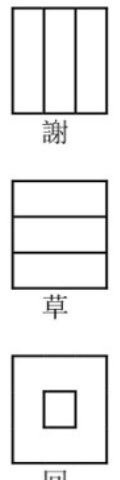

回
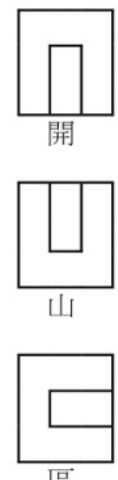

區
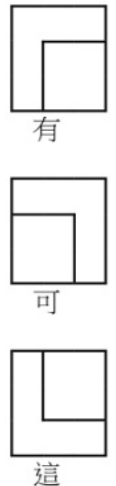

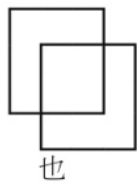

Tabela 2. Typy kompozycji znaków chińskich (N. Kordek 2013: 62; zob.: Y. Zhang 2000).

Znaki mogą być rozłożone na kilku poziomach, w zależności od stopnia złożoności; komponenty niższego rzędu mogą również być samodzielnymi znakami (zob. N. Kordek 2013: 62-74).

${ }^{2}$ Cecha ta wyraźniej widoczna jest obecnie w języku pisanym i w rejestrze formalnym. Jednocześnie należy pamiętać, że we współczesnym języku chińskim powszechne są wyrazy bisylabiczne i wielosylabiczne. 


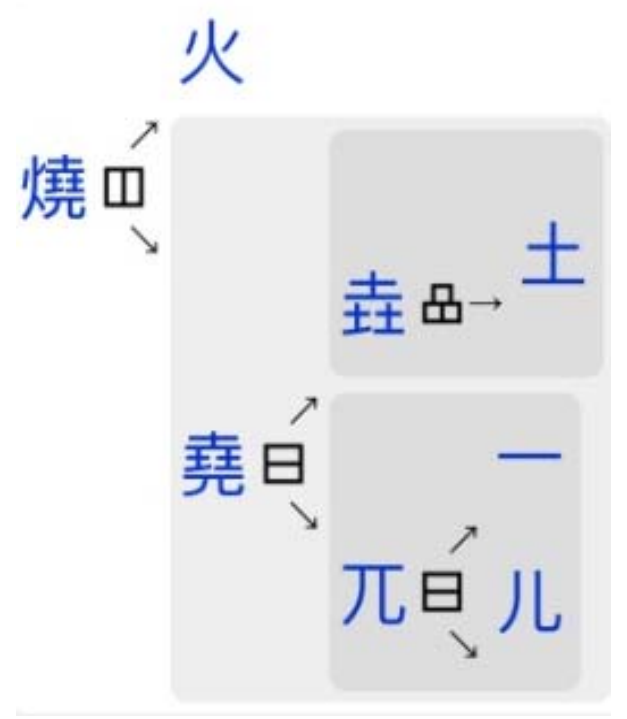

Schemat 1. Dekompozycja znaku [1].

Jeśli przyjąć podstawową klasyfikację funkcjonalną komponentów znaku³ ${ }^{3}$ którą N. Kordek (2013: 78-79) zaproponował za Chuang D. i Teng H. (2009), to oprócz komponentu wskazującego na wymowę i komponentu semantycznego (klucza semantycznego) można wskazać komponenty symboliczne. I tak klucz semantyczny 火 'ogień' w zapisie znaku 焼 'palić' komunikuje zakres znaczenia, a ten sam komponent 火 'ogień' w znaku 煩 'niepokoić' obok komponentu 頁 'głowa' nie wskazuje na znaczenie. $\mathrm{Z}$ punktu widzenie semantyki znaku pierwiastek graficzny zapisu w różnym stopniu odzwierciedla prototypowe znaczenie klucza semantycznego komponowanego znaku. Oznacza to kontinuum od wyrazistości znaczenia do wręcz mało czytelnej symboliki komunikowanej przez pierwiastek graficzny (zob. E. Zajdler 2011).

\section{Wyrazy homofoniczne w zapisie znakami}

Szukając relacji dźwięku i obrazu w zapisie znakami chińskimi poddano analizie znaki o tej samej wymowie na poziomie sylaby ,wen " oraz ,,lin”.

\footnotetext{
${ }^{3} \mathrm{~W}$ polskojęzycznej nomenklaturze stosuje się także pojęcie „pierwiastków” - oznaczające elementy graficzne znaku niezależnie od pełnionych przez nie funkcji zarówno w zapisie tradycyjnym jak i uproszczonym (E. Zajdler 2008: 115). Gdy jest to funkcja semantyczna, a zapis tradycyjny odwołuje się do kanonu 214 kluczy semantycznych (ang. radicals), mówi się o kluczu (pomijając nawet czasem doprecyzowanie ,semantyczny”). Uproszczony zapis tradycyjnego klucza semantycznego pozostaje ,pierwiastkiem”, jako że w tej grafii nie należy do kanonu 214 tradycyjnych kluczy. Pierwiastek w funkcji fonetycznej jest komponentem fonetycznym znaku (E. Zajdler 2008: 115).
} 
Zapis wyrazu 'język (pisany)' 文 (pinyin: wén) przyjmuje się tu zatem jako wyznacznik wymowy sylabemu. Znaki chińskie, w których komponent 文 wyznacza wymowę homofoniczną na poziomie sylaby wén (czyli wężej, zgodnie z wymową tonalą) i na poziomie sylabemu ,wen" (czyli szerzej, na poziomie zgodności struktury segmentalnej) omówione zostaną pod kątem klucza semantycznego.

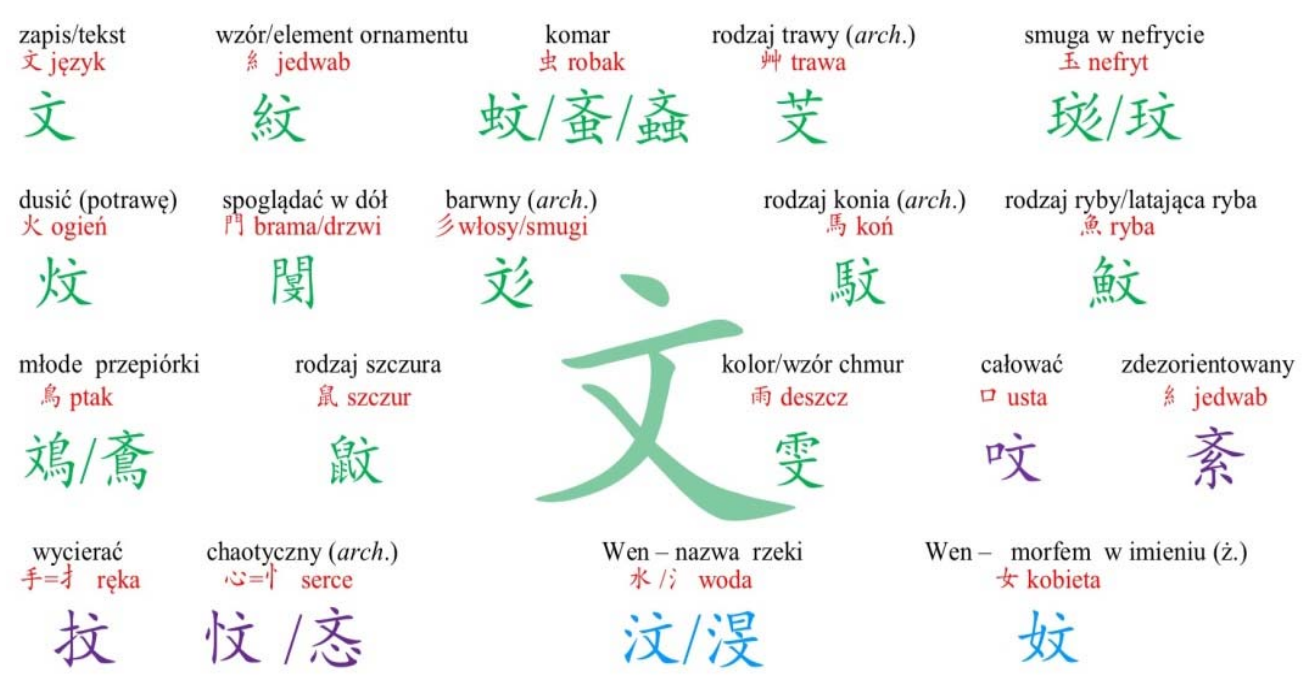

Schemat 2. Wyrazy z wymowa , wen".

I tak w zbiorze przedstawionych znaków:

- komponent semantyczny 系 ‘jedwab’ pojawia się razem z zapisem fonetycznym 文 $w$ dwóch różnych pozycjach, dając dwa różne znaki pisma chińskiego zapisujące dwa różne wyrazy: 紋 'pasek'/‘wzór'/'ornament' i 紊 'zdezorientowany'. Pierwszy zachowuje wymowę zgodną z tonem 文, drugi wymawiany jest w tonie trzecim. O ile w wyrazie 'ornament' można dostrzec odwołanie się do przędzy jedwabiu, o tyle abstrakcyjne pojęcie 'zdezorientowany' w żaden sposób nie jest desygnowane przez klucz semantyczny 'jedwab';

- wyraz 'komar' zapisany może być przez trzy różne oboczności 蚊 / 蚉/ 蚉, przy czym we wszystkich zachowany jest komponent fonetyczny 文 wskazujący na wymowę. Obecny jest także klucz semantyczny 虫 'robak' przyporządkowujący zapisany wyraz do określonej klasy semantycznej świata zwierząt/ insektów;

- wyraz 芠 wymawiany jest w tonie trzecim. Oboczność klucza semantycznego 州 /+ 'trawa' desygnuje znaczenie w archaicznym zapisie nazwy trawy;

- zapis wyrazu 'nefryt'玉, pojawia się w znakach jako klucz semantyczny w swojej formie obocznej 王; wraz z komponentem 文 zapisuje wyraz opisujący nefryt (tutaj: 'smuga w nefrycie'); to jeden z wielu wyrazów nazywających lub opisujących ten szlachetny, ważny w kulturze chińskiej kamień; 
- klucz semantyczny 火 'ogień' obecny jest w wyrazie nawiązującym do użycia ognia w przygotowywaniu potraw: 炆 'dusić';

- klucz 門 w podstawowym znaczneiu 'brama/ drzwi, wejście' nie wpisuje się $\mathrm{w}$ znaczenie wyrazu, w którym tutaj wraz z 文 się pojawia (闇 'spoglądać $\mathrm{w}$ dół'); należy jednak analizować go szerzej wraz z pierwiastkiem 日; znak 間 oznacza 'przerwa, przestrzeń, pomiędzy', zapewne odwołując się do przestrzeni między futryną drzwi; wtedy koncepcja przestrzenności bliższa jest kierunkom (tutaj: w dół);

- kmponent graficzny 乡 ‘włosy/smugi’ wskazuje w znaku 玟 na wzór w kształcie smugi, a w archaicznym wyrazie 㸚 na wielość barw;

- klucze semantyczne (będące także samodzielnymi znakami) komunikujące znaczenie określonych zwierząt: 馬 'koń', 魚 'ryba', 鳥 'ptak' czy 鼠 'szczur' $\mathrm{w}$ wyrazach wymawianych homofonicznie wén wskazują na zakres znaczenia związany z danym zwierzęciem; w istocie wyrazy te nazywają rodzaj/ gatunek zwierząt;

- klucz semantyczny 雨 'deszcz' przywołuje znaczenie 'chmury' i jej kolor/ wzór;

- wyraz 呅 (archaiczny wariant graficzny zapisu 吻) wymawiany w trzecim tonie oznacza 'całować'; oba znaki posiadają w zapisie klucz semantyczny $\square$ usta;

- klucz semantyczny 手 (oboczność graficzna ł ) 'ręka' wyznacza charakter czynności (działanie ręką), w tym wypadku 抆 'wycierać';

- komponent semantyczny 心 / 小 'serce' w wyrazie 忟 / 忘 'chaotyczny', odsyła się do stanu mentalnego; wyraz może mieć oboczny zapis dwoma znakami różniącymi się obocznością i pozycją klucza semantycznego;

- klucz semantyczny 水 / ' ‘ 'woda' widzimy w zapisie nazwy rzeki;

- a klucz 女 'kobieta' jest obecny w znaku używanym przede wszystkim do zapisu żeńskiego imienia - podobnie jak nazwa rzeki, morfem wymawiany jest w tonie czwartym.

Inny sylabem - „lin" - realizowany w czterech sylabach chińskich (pinyin linn, lín, lǐn, lìn), zapisany może być znakami z kilkoma różnymi grafemami wskazującymi na taką samą wymowę na poziomie sylabemu. Pokazane zostaną dwa grafemy o tej samej wymowie: 林 oraz 粦 jako komponenty fonetyczne znaków. Zapis wyrazu 'las' 林 jest ideogramem łączącym w zapisie dwa ideogramy drzewa 木 mù. Staje się on komponentem fonetycznym w złożeniach piktograficzno-fonetycznych. Natomiast znak 粦 złożony jest z piktogramu 米 'ryż' (wymowa $m \grave{\text { ) }}$ ) i ideogramu złożonego 舛 chuăn (z dwóch zwróconych do siebie „tyłem” grafemów, oznaczając 'odwrotność'/ 'przeciwieństwo'/ 'sprzeciwiać się'). Stanowi wczesną oboczność znaków 磷 / 燐. Jest kolejnym komponentem fonetycznym zapisującym sylabem „,in”, notacją pojawiającą się w dużo większej ilości morfemów/ wyrazów homofonicznych, niż komponent fonetyczny 林.

Oto kolejne dwa zbiory morfemów/wyrazów homofonicznych: 


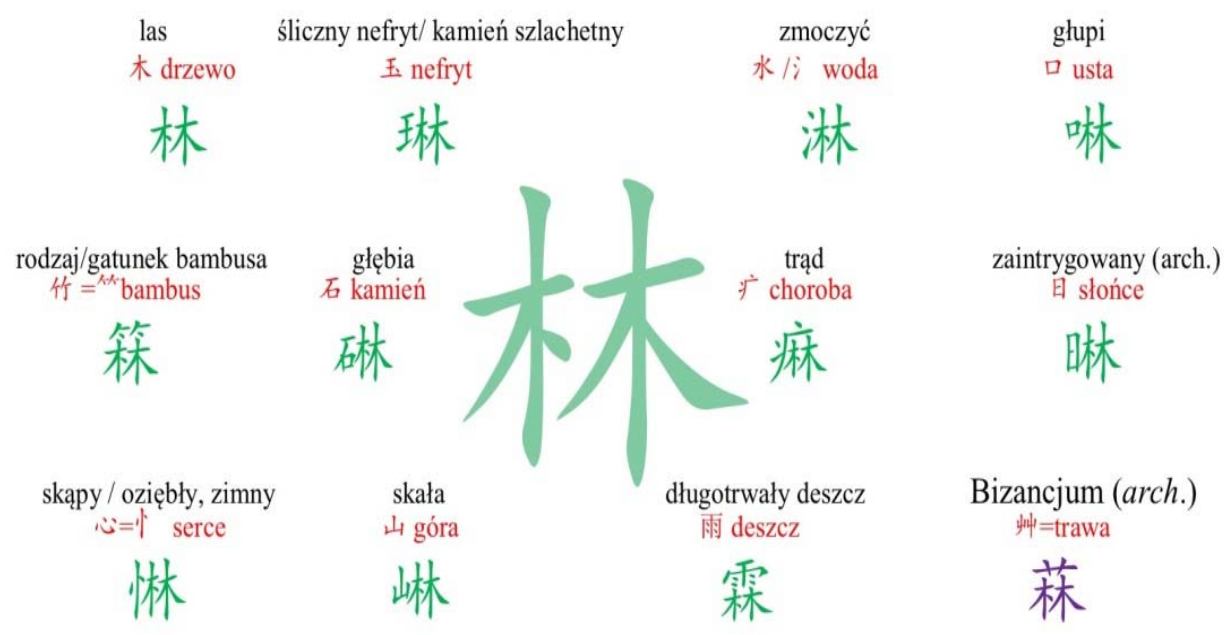

Schemat 3. Wyrazy z wymowa , lin".

Przedstawione w Schemacie 3. znaki zapisują kilkanaście wyrazów homofonicznych na poziomie sylabemu ,lin”. Większość jest homofoniczna na poziomie sylaby wymawianej w drugim tonie. Łączy je komponent fonetyczny 林. Regularnie po lewej stronie lub nad komponentem 林 dodany jest pierwiastek graficzny, który komunikuje treść, znaczenie, i przynajmniej w jakimś stopniu wskazuje na zakres znaczeniowy zapisanego znakiem morfemu. Nie znając wyrazu możemy z zapisu odgadnąć dziedzinę, ale już nie jego oczywiste znaczenie. Pojawienie się takiego znaku w danym kontekście tekstu może przybliżyć użytkownika do trafnej dedukcji znaczenia morfemu/ wyrazu zapisanego tym znakiem. Przejrzystość semantyczna znaku nie jest równa dla wszystkich wyrazów:

- pierwiastek 玉/王 'nefryt' jest wyraźnie semantyczny i stanowi klucz; odsyła nas do znaczenia 琳 'kamień szlachetny';

- klucz semantyczny 水/; 'woda' koresponduje ze znaczeniem 淋 'zmoczyć/ zmoczony';

- dla porównania, wyraz 啉 'głupi' ma niewiele wspólnego ze znaczeniem pierwiastka graficznego 口 'usta';

- klucz semantyczny 竹/ ${ }^{\text {r } ~ ' b a m b u s ', ~ p o d o b n i e ~ j a k ~ k l u c z e ~ s e m a n t y c z n e ~ n a z y-~}$ wające zwierzęta, przyporządkowuje wyraz do nazw roślin, w tym wypadku zapisując wraz z komponentem fonetycznym nazwę gatunku bambusa;

- klucz 石 'kamień' pojawia się w wyrazie 'głębia' i trudno go tu zinterpretować jako nośnik znaczenia, chociaż 石 jest kluczem semantycznym w wielu znakach, w tym w nazwach chemicznych;

- klucz semantyczny F ' choroba' wpisuje się w nazwę choroby 㾁 'trąd'; 
- archaiczny wyraz 晰 'zaintrygowany' zapisuje się znakiem z kluczem 日 'słońce' w żaden sposób nieprzystającym do znaczenia zapisanego wyrazu;

- z definicji abstrakcyjne znaczenie wyrazu 惏 'skąpy', 'oziębły' mieści się w zakresie cech i emocji człowieka komunikowanych przez element graficzny (klucz) 心 / 小 'serce'(zob. E. Zajdler 2011);

- klucz semantyczny 山 'góra' wpisuje się w znaczenie wyrazu 崊 ‘skała';

- podobnie jak klucz 雨 'deszcz' w opisywany charakter deszczu - 霖 'długotrwały deszcz';

- nie sposób natomiast odgadnąć z zapisu znakiem chińskim nazwy własnej Imperium Rzymskiego stosowanej w dawnych czasach w tekstach chińskich; w znak 菻 wymawiany, ,lin” wpisana jest oboczność klucza semantycznego 亚 / \# 'trawa'.

Schemat 4. przedstawia wyrazy wymawiane ,lin”, a zapisane znakami z komponentem fonetycznym 粦. Powtarzają się klucze semantyczne i różny stopień przejrzystości znaczenia w znaku.

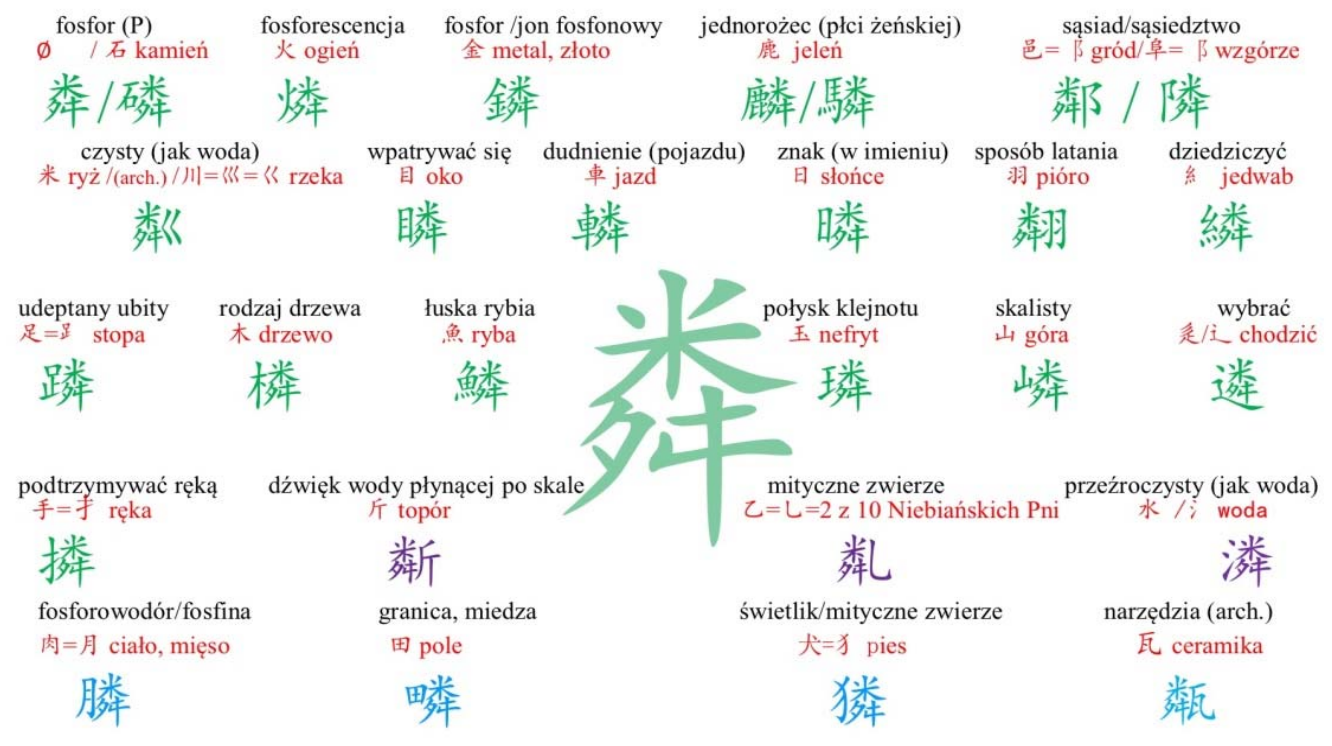

Schemat 4. Wyrazy z wymowa, ,lin”.

Zapis 粦 jest samodzielnym znakiem. Stanowi też komponent fonetyczny licznych znaków zapisujących morfem/ wyraz monosylabiczny, często o charakterze archaicznym (w formach obocznych znaków) lub stosowanych w tekście formalnym:

- odpowiednio, klucze 石'kamień, 火 'ogień', 金 'metal' oraz 肉/月 'mięso/ ciało’ wpisują się nazwy chemiczne związków czy zjawisk/ procesów chemicznych;

- klucze semantyczne 鹿 ‘jeleń’ oraz 馬 ‘koń’ oraz klucz 乙/し/つ ‘2. z 10 Niebiańskich Pni’ w wyrazach 麟 / 驎 oraz 粼 komunikują znaczenia ściśle zwią- 
zane z kulturą - 'mityczne zwierzę'; znaczenie to jest czytelne jedynie w kontekście tradycji i przyjętej konwencji świata mitycznego. Bez precyzyjnego opisu, obraz zwierząt/ postaci mitycznych tworzymy na podstawie własnych doświadczeń kulturowych;

- klucze 邑/ ß 'gród’ i 阜/ ß ‘wzgórze (w zasięgu wzroku)' znajdujemy w zapisie wyrazu 鄰 'sąsiad'/ 'sąsiedztwo';

- klucz semantyczny o znaczeniu 目 'oko’ pojawia się w wyrazie nawiązującym do działania 瞵 'patrzeć/ wpatrywać się’;

- klucz 車 'pojazd' za sprawą dźwięku poruszającego się pojazdu obecny jest w zapisie zreduplikowanej onomatopei 轔轔'dudnić'/ 'stukot';

- zapis morfemu 暽 używanego w imionach zawiera klucz 日 'słońce' - znaczenie w wieli kulturach pozytywne;

- dalej komponent semantyczny 羽 'pióro' odsyła do czynności latania w słowie 粼 'sposób latania';

- a klucz semantyczny 手/ f 'ręka' do czynności z nią związanej - 撛 'podtrzymanie (ręką)';

- klucz 糸 ‘jedwab’ przywołuje koncepcję ciągłości zobrazowanej jedwabną przędzą, ale przeniesionej na znaczenie więzi między pokoleniowej w wyrazie 繗'dziedziczyć';

- klucz 足 / 足 'stopa' konsekwentnie wskazuje na skutek wynikający z czynności, w tym przypadku deptania: 蹸 'ubity'/ 'udeptany';

- klucz 木 mù ‘drzewo’ obecny jest w zapisie nazwy gatunku drzewa;

- klucz 魚 'ryba' obecny jest w zapisie słowa 鱗 'łuska rybna';

- komponent semantyczny 玉/王 'nefryt' ponownie wskazuje na cechę drogocennego kamienia - 璘 ' połysk klejnotu’;

- klucz semantyczny 山 'góra' wpisuje się w znaczenie wyrazu 嶙 'skalisty', choć trudno tu mówić o wyrazistości znaczenia - góra nie musi przecież być skalista;

- natomiast komponenty semantyczne 水/; 'woda' oraz 川 / 《 / 《 'rzeka' odsyłają nas w dwóch znakach 粼 $\mathrm{i}$ 潾 do cechy: 'czysty, przejrzysty (jak woda)';

- znak 疄 'granica/miedza' odwołuje się bezpośrednio do klucza 田 'pole', zawsze przywołującej jakąś formę ,rozgraniczenia”;

- oboczność klucza semantycznego 犬/ 犭 ‘pies’ obecna jest w znaku zapisującym 'mityczne zwierzę';

- a komponent sermantyczny $氏$ 'ceramika'/ 'dachówka ceramiczna' pojawia się zapisie archaicznego wyrazu 'narzędzia';

- zupełnie nieprzejrzysta jest semantyka znaków z kluczem semantycznym 斤 'topór' i 定 / 连 'chodzić', odpowiednio zapisujących wyraz 斴 'dźwięk wody płynąca po skale' oraz 遴 'wybierać'. 
Przedstawiono zbiory homofonicznych, na poziomie sylabemów, morfemów/ wyrazów zapisanych znakami chińskimi z jednym komponentem fonetycznym dla sylabemu „wen" i dwoma różnymi komponentami graficznymi zapisującymi wymowę sylabemu , ,in". W sumie zebrano w pracy kolejno 19 i 37 morfemów (zapisanych odpowiednio 25 i 40 różnymi znakami pisma chińskiego). W omawianych zbiorach największą zgodność homofoniczną wykazuje sylaba ,lin" wymawiana w tonie drugim -29 z przedstawionych morfemów o różnym zapisie wymawia się tak samo na poziomie sylaby. Morfemy te mogą stanowić monosylabiczne wyrazy najczęściej w tekście pisanym, języku specjalistycznym lub tekstach literackich/ klasycznych. Prawdopodobnie ze względu na różny czas pochodzenia pozostają czasami wzajemnie w relacji oboczności. Mogą być także synonimicznym monosylabicznym wyrazem w tekście pisanym dla używanego w mowie dwu- , trzy- lub wielosylabowego wyrazu, szczególnie w nazwach fachowych w językach specjalistycznych.

\section{Pismo chińskie a dydaktyka języka}

Zaprezentowany w artykule materiał językowych pokazuje wycinek powszechnego zjawiska - wysoką homofoniczność na poziomie sylabemu i sylaby w języku chińskim. Istnieje też częściowa homofonia segmentu mowy odwołująca się do zbieżności nagłosu lub wygłosu między morfemami, a odzwierciedlona często w zapisie przez określony komponent fonetyczny danego znaku. Przykładem mogą być wygłosy -eng, -ing, -ang i nagłosy $p-/ b-, q-/ j$-, $k$-/ $/ h-/ \varnothing$ - implikowane w zapisie odpowiednio przez obecność komponentu fonetycznego 朋 péng, 青 qīng, 宇 kàng, w istocie samodzielnych znaków pisma zapisujących morfemy: 'przyjaciel', 'zielony', 'nadmierny/ wysoki'. Homofonię częściową można wskazać w morfemach zapisanych na przykład znakami:

- 㮶, 傰, 疬, 崩, 䋚, 䙖, 䨒 $\mathrm{i}$ 奟 (zapis wymowy pinyinem: bēng), 繃 $\mathrm{i}$ 袺 (pinyin běng) oraz 嘣, 蹦, 塴 $\mathrm{i}$ 鏰 (pinyin bèng); zbieżność nagłosu w morfemach: 炏 ping, 萠 $p \bar{a} n \mathrm{i}$ 崩 péi;

- 精, 睛, 腈 $\mathrm{i}$ 聙 (pinyin jīng), 靖, 婧 (pinyin jìng);

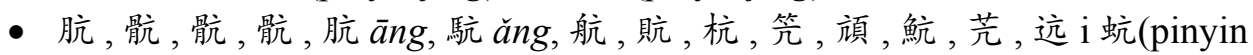
háng), 沆 $\mathrm{i}$ 䟽 (pinyin hàng); zbieżność nagłosu w morfemach: 吭 $\mathrm{i}$ 妔 (pinyin kēng).

Dostrzegalne są liczne pary minimalne na poziomie sylabemów, w których stopień zbliżenia/ zwarcia narządów mowy i dźwięczność głosek w nagłosie stanowią w systemie fonologicznym języka chińskiego o cechach fonologicznie relewantnych. Pojawia się też zerowa alternacja spółgłosek nagłosu.

Mimo, że absolutnie nie można mówić o zapisie fonetycznym w języku chińskim, zależności między sekwencją dźwięków mowy i komponentami fonetycznymi w zapisie przybliżającymi wymowę obecne w znakach piktograficzno-fonetycznych, obok zakresu semantycznego znaku, powinny być brane pod uwagę w nauczaniu języka chińskiego jako LF. Są one odpowiedzią na pytanie, jaką rolę pełni obraz wobec dźwięku w procesie przyswajania języka chińskiego. W języku mocno ograniczonym 
monosylabicznością morfemów i homofonią sylabemów/ sylab i ich segmentów, zapis znakami różnicujący konotację z jednej strony przede wszystkim wspiera zakres przyswajanej leksyki, z drugiej, szerzej, jest ścieżką dostępu do kultury i cywilizacji. Warto przy okazji przypomnieć, że analfabetyzm społeczny i funkcjonalny, bo za taki należałoby uznać brak umiejętności pisania i czytania w CFL, ogranicza funkcje poznawcze w zakresie rozwijania kompetencji językowych i sprowadza je do niskiego poziomu biegłości językowej. Stawiając zatem za cel nauczenie języka (mowy i komunikacji), nie można pominąć kompetencji lingwistycznych (ortoepicznej i fonologicznej) integrujących dźwięk (tj. mowę) i obraz (zapis znakami) w języku chińskim.

\section{Bibliografia}

Chen Ping, (1999), Modern Chinese: History and Sociolinguistics.

Chinese Academy of Social Sciences, Institute of Language 中国社会科学院语言研 究所词典编辑 (red.), (1991), 《现代汉语词典》Xiandai Hanyu Cidian.

Shanghai Cishu Chubanshe. 上海辞书出版社, (1989), 《辞海》Cihai.

Chuang Der-ming 莊德明/ Teng Hsian-ying 鄧賢瑛, (2009), 漢字構形資料庫的研 發與應用 [ang. Research and Development of Chinese Characters Information Database and Its Appliation].

(URL http://cdp.sinica.edu.tw/service/ documents/T090904.pdf). [Pobrano 1.10.2017].

Harbaugh, R., (1998), Chinese Characters: A Genealogy and Dictionary [chin. Zhongwen zi pu 《中文字譜》].

Kordek, N. (2013), On Some Quantitative Aspects of the Componential Structure of Chinese Characters. Poznań.

Künstler, M.J., (2000), Języki chińskie. Warszawa.

Mathews, R. H., (1956), Chinese-English Dictionary. Cambridge/ Harvard.

Oszanin I.M. (red.), (1983), Balszoj Kitajsko-Russkij Slowar, [ros.Большой китайско-русский словарь]. Moskwa.

Polański, K. (red.), (2003), Encyklopedia językoznawstwa ogólnego. Wrocław.

Su Shenghao 蘇生豪 (red.), (1987), Jianming hanyingcidian《简明漢英鳝典》.

Wilder G.D./ J.H. Ingram, (1972), Analysis of Chinese Characters.

Zajdler, E., (2011), Graficzna reprezentacja świata w piśmie chińskim (w:) H.Kardela, Z.Muszyński, M.Rajewski (red.), Główne pojęcia kognitywistyki: empatia, obrazowanie, kontekst. Lublin.

Zhang Ding 張鼎(1985), Mei ri yi zi. 《每日一字》

Zhang Yujin 张玉金, (2000), 论汉字的部件拆分和字符拆分 [ang. On the Decomposition of Chinese Characters into Components and Symbols], 《辽宁师范大学 学报 (社會科學版) 》[ang. ,Journal of Liaoning Normal University (Social Sciences)"] 4. 67-69.

Zhonghua xiaozidian《中華小字典》, (1985).

Zuo Minan 左民安/Wang Jinzhong 王尽忠, (1998).Hanzi bushou jiangjie《汉字部 首讲解》。

[1] https://www.mdbg.net/chinese/dictionary [Pobrano 1.10.2017].

[2] https://zidian.911 cha.com/zi5445.html [Pobrano 1.10.2017].

[3] http://www.zdic.net/z/16/js/5445.htm [Pobrano 1.10.2017]. 